\title{
Isolation and Characterization of a Prolidase from Streptococcus cremoris H61
}

\author{
Shuichi Kaminogawa, Norihiro Azuma, In-Kyu Hwang, \\ Yasunori SuzuKI and Kunio YamaUCHI \\ Department of Agricultural Chemistry, \\ The University of Tokyo, Bunkyo-ku, Tokyo 113, Japan
}

Received May 4, 1984

\begin{abstract}
A prolidase with a molecular weight of 43,000 was purified to homogeneity from a cell-free extract of Streptococcus cremoris H61. The optimum pH of the enzyme was in the range of 6.5 to 7.5. The hydrolyzing activity was specific for dipeptides of the X-Pro type. Kinetic constants for 4 dipeptides (Leu-Pro, Phe-Pro, Val-Pro and Ala-Pro) were estimated. $\mathrm{Km}$ values were not very different for these substrates, but $V_{\max }$ values were quite different (Leu-Pro $>$ Phe-Pro, Val-Pro $>$ Ala-Pro). The enzyme was activated by cobalt ion and inactivated by metal-chelating agents or with 2-mercaptoethanol.
\end{abstract}

The amino peptidase present in such bacteria as Escherichia coli and Salmonella typhimurium plays an important role in the peptide catabolism. ${ }^{1)}$ The several kinds of aminopeptidases with different substrate specificities have been reported. ${ }^{1)}$ The aminopeptidases of lactic streptococci may function in the peptide catabolism as the bacteria described above do.

In the case of dairy lactic bacteria, it is considered that their aminopeptidases may also have some significance in cheese ripening. The aminopeptidases released from autolyzed cells in cheese seem to contribute to the formation of amino acids from casein under the cooperation of proteinases present in cheese.

We have purified and characterized a dipeptidase $^{2,3)}$ from Streptococcus cremoris H61. Thereafter, we have found the presence of aminopeptidase which was capable of hydrolyzing dipeptides of the X-Pro type in the same strain. This type of the enzyme had been found in porcine intestinal mucosa ${ }^{4}{ }^{4}$ horse erythrocyte, ${ }^{5)}$ rat brain ${ }^{6)}$ and Arthrobacter, ${ }^{7)}$ and is designated as prolidase, proline dipeptidase and imidodipeptidase (EC 3.4.13.9). Prolidases from porcine ${ }^{8,9,10)}$ and bovine intestine $^{11)}$ have been purified and characterized.
The physiological significance of these enzymes is considered to be the cooperative hydrolysis with other proteases. ${ }^{12)}$ We purified and characterized the prolidase from Str. cremoris $\mathrm{H} 61$ and found that the enzyme had different molecular properties from those of mammalian intestine. The present paper describes these results.

\section{MATERIALS AND METHODS}

Reagents. DEAE-cellulose was purchased from Whatman Co. (DE-23), London, hydroxyapatite from Seikagaku-Kogyo Co., Tokyo, and Sephadex G-150 from Pharmacia Fine Chem., Uppsala. Gly-L-Ser and L-Ala-LTyr were obtained from Seikagaku-Kogyo Co., Tokyo, DL-Leu-L-Phe and DL-Leu-Gly-DL-Phe from TokyoKasei Co., Tokyo. Cbz-Gly-L-Ala was obtained from Cyclo Chem. Corp., California, DL-His-DL-His from Nutritional Biochem. Co., Ohio, and the other peptides were purchased from Sigma. Bestatin was a kind gift from Dr. T. Aoyagi, the Institute of Microbial Chemistry, Tokyo. All other reagents were of guaranteed grade. Constituent amino acids of the peptide substrates used are of L-configuration, unless otherwise specified.

Organism and cell-free extract. Streptococcus cremoris H61 was a kind gift from Dr. T. Morichi, the National Institute of Animal Industry, Tsukuba, Japan. The organism was grown in a tomato medium. ${ }^{1)}$ The cells were harvested by centrifugation at $5000 \times g$ for $30 \mathrm{~min}$ at $4^{\circ} \mathrm{C}$ 
and washed three times with sterile saline solution $(0.85 \%$ $\mathrm{NaCl}$ ). The washed cells were resuspended in $50 \mathrm{~mm}$ sodium phosphate buffer at $\mathrm{pH} 6.0$ and lyophilized. The cell-free extract was prepared by the method $^{2)}$ described previously.

Assay of enzyme activity. Prolidase activity and the hydrolytic activity for peptides containing a proline residue were measured using the ninhydrin method of Yaron and Mlyner. ${ }^{13)}$ The reaction mixture containing $0.1 \mathrm{ml}$ of $1 \mathrm{~mm}$ X-Pro dipeptide and the enzyme solution was made in $50 \mathrm{~mm}$ sodium phosphate buffer at $\mathrm{pH} 6.0$ and the final volume was adjusted to $1 \mathrm{ml}$ by adding the same buffer. After incubation at $37^{\circ} \mathrm{C}$ for $30 \mathrm{~min}$, the reaction was stopped by the addition of $2.5 \mathrm{ml}$ of glacial acetic acid. The proline released by the enzyme was estimated by measuring the extinction at $480 \mathrm{~nm}$ of the red color formed after adding $2.5 \mathrm{ml}$ of ninhydrin reagent and heating in boiling water for $30 \mathrm{~min}$.

Assay of protein. Protein concentration was measured by the method of Lowry et al. ${ }^{15)}$ using bovine serum albumin as the standard.

Polyacrylamide-gel electrophoresis (PAGE). Disc-PAGE was performed on $7.5 \%$ gel by the method of Davis. ${ }^{16)}$

Amino acid analysis. Amino acid composition of the enzyme was tentatively estimated in a Hitachi 835 amino acid analyzer after hydrolysis in $6 \mathrm{~N} \mathrm{HCl}$ for $24 \mathrm{hr}$ at $110^{\circ} \mathrm{C}$

\section{RESULTS}

\section{Isolation of the enzyme}

The cell-free extract was fractionated with ammonium sulfate. The precipitate at $80 \%$ of ammonium sulfate saturation was collected and dialyzed against $10 \mathrm{~mm}$ sodium phosphate buffer at $\mathrm{pH} 6.0$ for $24 \mathrm{hr}$ at $4^{\circ} \mathrm{C}$. The dialyzed solution $(73 \mathrm{ml})$ was applied to a column $(2.0 \times 50 \mathrm{~cm})$ of DEAE-cellulose which had been equilibrated with $10 \mathrm{~mm}$ sodium phosphate buffer at $\mathrm{pH}$ 6.0. After being washed with a small volume of the same buffer, the enzyme adsorbed was eluted by a linear gradient of sodium chloride from 0.15 to $0.6 \mathrm{M}$ in the same buffer and the eluent was collected in $10 \mathrm{ml}$ portions. The fractions from No.67 to $82(\mathrm{NaCl}$ concentration: $0.3 \sim 0.35 \mathrm{M})$ were found to contain dipeptidase having some activity for Leu-Pro. These fractions were combined and dialyzed against $10 \mathrm{~mm}$ sodium phosphate buffer at $\mathrm{pH} 6.0$.

The enzyme solution $(160 \mathrm{ml})$ eluted from a DEAE-cellulose column was applied to a column of hydroxyapatite $(1.8 \times 9.0 \mathrm{~cm})$, which had been equilibrated with $10 \mathrm{~mm}$ sodium phosphate buffer at pH 6.0. The enzyme was eluted in $5 \mathrm{ml}$ portions by a linear gradient of sodium phosphate concentration from 0.01 to $0.4 \mathrm{M}$ at $\mathrm{pH}$ 6.0. The prolidase activity was found in fractions from No.75 to 98 (phosphate concentration: $0.16 \sim 0.3 \mathrm{M}$ ) and these were collected and dialyzed against sodium phosphate buffer at $\mathrm{pH} 6.0$.

The enzyme solution $(114 \mathrm{ml})$ obtained was concentrated to about $1 \mathrm{ml}$ on a CollodionBag-SM 13200 (Sartrius Membrane Filter $\mathrm{GmbH}$ ) and applied to Disc-PAGE. After electrophoresis at $4^{\circ} \mathrm{C}$ for $2 \mathrm{hr}$, the gels were sliced at intervals of $2 \mathrm{~mm}$. The fractions possessing hydrolysis activity for Leu-Pro were collected and the enzyme was extracted with $10 \mathrm{~mm}$ phosphate buffer at $\mathrm{pH} 6.0$. The extract was dialyzed against the phosphate buffer and then applied to a column of Sephadex G-150 $(2.0 \times 50 \mathrm{~cm})$, which had been equilibrated with the same buffer. Elution was carried out at $4{ }^{\circ} \mathrm{C}$. The flow rate was $5 \mathrm{ml}$ per $\mathrm{hr}$ and the eluate was collected in $5 \mathrm{ml}$ portions. The fractions having a hydrolysis activity for Leu-Pro were pooled and used for the following experiments.

The purification process is summarized in Table I. The enzyme was purified about 490fold over the cell-free extract and the yield of activity was about $30 \%$ in the case of using LLeu-L-Pro as the substrate.

Figure 1 shows the Disc-PAGE pattern of the enzyme and the activity in the gel slice. In the Disc-PAGE pattern, a single band corresponding to the enzyme activity was observed with a relative mobility of 0.8 against the dye front.

\section{Molecular weight estimation}

The molecular weight of the enzyme was estimated by gel filtration on a column of Sephadex G-150 in the manner described above. Bovine milk $\alpha$-lactalbumin, hen egg 
Table I. Purification of Prolidase

\begin{tabular}{lccccc}
\hline \multicolumn{1}{c}{ Step of purification } & $\begin{array}{c}\text { Total } \\
\text { protein } \\
(\mathrm{mg})\end{array}$ & $\begin{array}{c}\text { Total } \\
\text { activity* } \\
\text { (units) }\end{array}$ & $\begin{array}{c}\text { Specific } \\
\text { activity* } \\
\text { (units/mg) }\end{array}$ & $\begin{array}{c}\text { Purification } \\
\text { Yield of } \\
\text { activity* } \\
(\%)\end{array}$ \\
\hline Cell-free extract & 454.9 & 9862 & 21.7 & 1 & 100 \\
$\left(\mathrm{NH}_{4}\right)_{2} \mathrm{SO}_{4}$ precipitate $(80 \%)$ & 320.2 & 7233 & 25.5 & 1.2 & 73.3 \\
DEAE-cellulose chromatography & 42.2 & 6925 & 164.0 & 7.6 & 70.2 \\
Hydroxylapatite chromatography & 11.5 & 5423 & 472.2 & 21.8 & 55.0 \\
Disc-PAGE gel-slice extract & 0.26 & 2759 & 10601.7 & 488.6 & 29.0 \\
\hline
\end{tabular}

* Activity was measured by using Leu-Pro as a substrate.

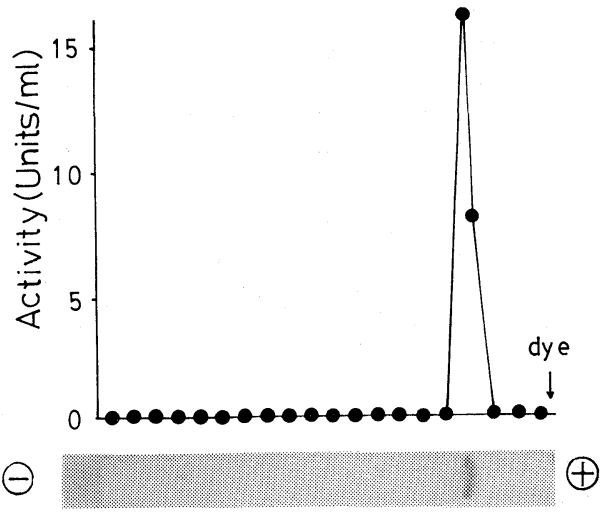

FIG. 1. Disc-PAGE Pattern of Prolidase and the Hydrolyzing Activity in the Gel Slice.

Leucylproline was used as a substrate.

ovalbumin, bovine serum albumin and soybean trypsin inhibitor were used as standard proteins. The molecular weight of this enzyme was estimated to be 43,000 by a plot of the elution volume against the logarithm of molecular weight of each protein.

\section{Amino acid composition}

The amino acid composition of the enzyme is shown in Table II. The content of acidic amino acids was relatively high, which might cause fast migration of this enzyme on DiscPAGE (relative mobility $=0.8$ ).

\section{Substrate specificity}

The hydrolytic activity of the enzyme on various peptides was investigated. Table III shows the relative rates of hydrolysis of various substrates by the enzyme (Leu-Pro as 1).
Table II. Amino Acid Composition of Prolidase

\begin{tabular}{lc}
\hline \multicolumn{1}{c}{ Amino acid } & Mol\% \\
\hline Aspartic acid & 7.8 \\
Threonine & 4.4 \\
Serine & 13.6 \\
Glutamic acid & 9.4 \\
Proline & 2.9 \\
Alanine & 9.9 \\
Half Cystine & 2.3 \\
Valine & 5.3 \\
Methionine & 0.2 \\
Isoleucine & 4.0 \\
Leucine & 5.3 \\
Tyrosine & 2.5 \\
Phenylalanine & 2.6 \\
Lysine & 4.1 \\
Histidine & 5.3 \\
Arginine & 3.2 \\
Tryptophan & n.d.* \\
\hline
\end{tabular}

The content of glycine was not determined because the glycine was contained in the enzyme preparation from the acrylamide gel slice. ${ }^{16)}$

$*_{\text {n.d. }}=$ not determined.

It was capable of hydrolyzing highly X-Pro type dipeptides such as Leu-Pro, Phe-Pro, Val-Pro and Ala-Pro. None of the other peptides or carbobenzoxypeptides were hydrolyzed.

\section{Effect of $\mathrm{pH}$ on the enzyme activity}

The optimun $\mathrm{pH}$ for enzyme activity was measured with Leu-Pro using the buffers in a $\mathrm{pH}$ range from 5.2 to 8.8 . Buffers used were $0.1 \mathrm{M}$ sodium phosphate buffer for $\mathrm{pH} 5.2$ to 8.0 and $0.1 \mathrm{M}$ Tris- $\mathrm{HCl}$ buffer from $\mathrm{pH} 7.2$ to 8.8. The optimum $\mathrm{pH}$ of the enzyme was in the $\mathrm{pH}$ range of 6.5 to 7.5 . 
Table III. Relative Activity of the Enzyme for Various Synthetic Peptides

\begin{tabular}{|c|c|c|c|c|c|c|}
\hline & Peptide & $\begin{array}{l}\text { Relative } \\
\text { activity }\end{array}$ & Peptide & $\begin{array}{l}\text { Relative } \\
\text { activity }\end{array}$ & Peptide & $\begin{array}{l}\text { Relative } \\
\text { activity }\end{array}$ \\
\hline \multirow{4}{*}{ (A) } & Leu-Pro & 1.00 & Poly-Pro & 0.00 & Ala-Pro & 0.30 \\
\hline & Gly-Pro & 0.00 & Phe-Pro & 0.58 & Val-Pro & 0.52 \\
\hline & Gly-Pro-Ala & 0.00 & Gly-Pro-Glu & 0.00 & Gly-Pro-Leu & 0.00 \\
\hline & Pro $-\beta-\mathrm{Na}$ & 0.00 & & & & \\
\hline \multirow{15}{*}{ (B) } & Gly-Leu & 0.00 & Ala-Tyr & 0.00 & Pro-Gly & 0.00 \\
\hline & Glu-Phe & 0.00 & Ala*-Gly & 0.00 & Pro-Val & 0.00 \\
\hline & Gly-Val & 0.00 & Ala-Leu & 0.00 & Pro-Tyr & 0.00 \\
\hline & Leu-Gly & 0.00 & Ala*-Val* & 0.00 & Pro-Leu & 0.00 \\
\hline & Leu-Val & 0.00 & Ala*-Ser* & 0.00 & His-Leu & 0.00 \\
\hline & Leu*-Tyr & 0.00 & Ala*-Met* & 0.00 & His-Gly & 0.00 \\
\hline & Leu*-Phe* & 0.00 & Ala*-Phe* & 0.00 & His-Ser & 0.00 \\
\hline & Val-Leu & 0.00 & Val-Gly & 0.00 & Glu-Val & 0.00 \\
\hline & Gly-Gly-Gly & 0.00 & Ala*-Gly-Gly & 0.00 & Cbz**--Gly-Phe & 0.00 \\
\hline & Gly-Gly-Val & 0.00 & Ala*-Leu*-Gly & 0.00 & Cbz**-Gly-Pro & 0.00 \\
\hline & Gly-Gly-His & 0.00 & Leu-Leu-Leu & 0.00 & $\mathrm{Cbz}^{* *}$-Gly-Val & 0.00 \\
\hline & Gly-Phe-Ala & 0.00 & Leu*-Gly-Phe* & 0.00 & Cbz**-Gly-Ala & 0.00 \\
\hline & Val-Gly-Gly & 0.00 & Leu-Gly-Gly & 0.00 & Cbz**-Gly-Gly & 0.00 \\
\hline & Val-Tyr-Val & 0.00 & Pro-Gly-Gly & 0.00 & $\mathrm{Cbz}^{* *}$-Gly-Ala & 0.00 \\
\hline & Glu-Val-Phe & 0.00 & & & & \\
\hline
\end{tabular}

* DL-Amino acid.

** Carbobenzoxy.

A) The enzyme activity was measured by the method of Yaron and Mlyner. ${ }^{13)}$

B) The enzyme activity was measured by the method of Matherson and Tattride. ${ }^{14)}$ The rate of Leu-Pro hydrolysis was taken as 1 .

Effect of temperature on the enzyme activity and thermal stability

The optimum temperature for the enzyme was determined with Leu-Pro as a substrate by incubating at $\mathrm{pH} 7.0$ for $30 \mathrm{~min}$, and was found to be $40^{\circ} \mathrm{C}$. The enzyme was stable up to $40^{\circ} \mathrm{C}$ for $30 \mathrm{~min}$ at $\mathrm{pH} 7.0$, but rapidly lost its activity at temperatures higher than $40^{\circ} \mathrm{C}$.

\section{Effect of metal ions and reagents on the enzyme activity}

The effect of some metal ions on the enzyme activity was checked using Leu-Pro as the substrate. The results are shown in Table IV. The activity was not affected by $\mathrm{Co}^{++}, \mathrm{Ca}^{++}$ and $\mathrm{Mg}^{++}$. It was weakly inhibited by $\mathrm{Zn}^{++}$ and completely inhibited by $\mathrm{Hg}^{++}, \mathrm{Cu}^{++}$and $\mathrm{Fe}^{++}$. After removing the metal ions from the enzyme by treating with EDTA, the activity lost was only recovered by the addition of $\mathrm{Co}^{++}$

The effect of some reagents on the enzyme
Table IV. Effect of Metal Ions on the ENZYME ACTION

After preincubation with $1 \mathrm{~mm}$ of each metal ion for $10 \mathrm{~min}$, the enzyme solution was added to the reaction mixture and incubation was performed at $37^{\circ} \mathrm{C}$ and $\mathrm{pH}$ 7.0 for $30 \mathrm{~min}$. Leu-Pro was used as the substrate at a concentration of $0.1 \mathrm{mM}$.

\begin{tabular}{cc}
\hline Metal ions (1 mM) & Relative activity \\
\hline $\mathrm{CoCl}_{2}$ & 131.0 \\
$\mathrm{CaCl}_{2}$ & 127.0 \\
$\mathrm{MgCl}_{2}$ & 126.0 \\
$\mathrm{MnCl}_{2}$ & 16.4 \\
$\mathrm{ZnCl}_{2}$ & 75.3 \\
$\mathrm{CuSO}_{4}$ & 0.0 \\
$\mathrm{FeCl}_{2}$ & 0.0 \\
$\mathrm{HgCl}_{2}$ & 0.0 \\
$\mathrm{None}$ & 100 \\
\hline
\end{tabular}

activity was also examined, the results being shown in Table V. The enzyme was completely inhibited by EDTA and 1,10-phenanthroline, considerably inhibited by $p$-chloromercuri- 
Table V. EfFect of Various Chemicals ON THE ENZYME ACTIVITY

Incubation was performed in the same way as described in Table IV, after preincubation with each chemical.

\begin{tabular}{lc}
\hline Reagents (final conc. mM) & Relative activity \\
\hline EDTA (1) & 0 \\
1,10-Phenanthroline (1) & 0 \\
$p$-Chloromercuribenzoate & 67 \\
$(1)$ & 65 \\
$N$-Ethylmaleimide (1) & 84 \\
Monoiodoacetic acid (1) & 30 \\
2-Mercaptoethanol (1) & 94 \\
Cysteine (0.5) & 84 \\
Bestatin (0.0016) & 100 \\
None & \\
\hline
\end{tabular}

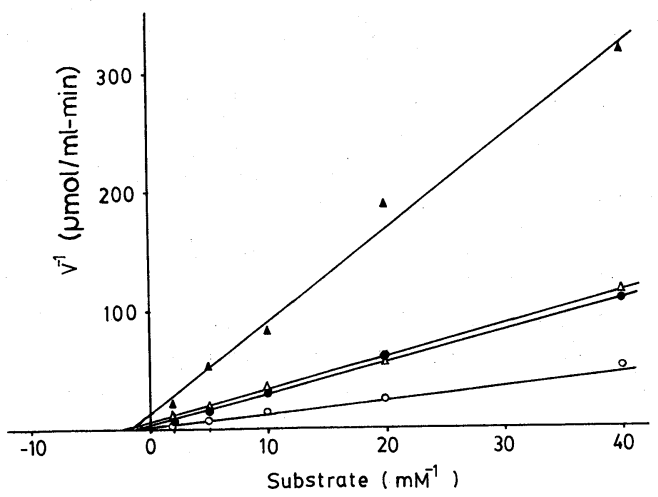

FIG. 2. Kinetics of Prolidase for X-Pro Type Dipeptides.

- - - Leu-Pro; - - - Phe-Pro; $-\triangle-$, Val-Pro; $-\mathbf{\Delta}-$, Ala-Pro. Incubation was performed at $37^{\circ} \mathrm{C}$ and $\mathrm{pH} 6.0$ for $15 \mathrm{~min}$.

benzoate or $N$-ethylmaleimide, and was strongly inhibited by 2-mercaptoethanol (in the presence of $10 \mathrm{~mm}$ 2-mercaptoethanol, inhibited completely). It was, however, slightly affected by other sulfhydryl reagents, S-S dissociating agents and bestatin.

\section{Kinetics of the enzyme}

The kinetic constants for the hydrolysis of $\mathrm{X}$-Pro peptides were determined by measuring the amount of proline released. Mixture solutions of various concentrations of substrates containing $40 \mu \mathrm{l}$ of the enzyme solution were prepared in $10 \mathrm{~mm}$ phosphate buffer at $\mathrm{pH} 6.0$ to make a final volume of $1 \mathrm{ml}$. After in- cubation for $15 \mathrm{~min}$ in the same manner as described above, the amount proline released was measured and the constants of $\mathrm{Km}$ and $V_{\max }$ were determined by Lineweaver-Burk plotting. As substrates, Leu-Pro, Phe-Pro, Ala-Pro and Val-Pro were chosen. The results are shown in Fig. 2. $\mathrm{Km}$ values were calculated to be $0.82,0.76,0.41$ and $0.61 \mathrm{~mm}$ for Leu-Pro, Phe-Pro, Val-Pro and Ala-Pro, respectively. The $K m$ values were not much different for these four substrates but the $V_{\max }$ values were quite different from each other-0.67, 0.29, 0.17 and $0.08 \mu \mathrm{mol} / \mathrm{ml} \cdot \mathrm{min}$, respectively.

\section{DISCUSSION}

A prolidase that is capable of hydrolyzing dipeptides of the X-Pro type was isolated from a cell-free extract of Str. cremoris H61. The purified enzyme appeared homogeneous from the results of Disc-PAGE (Fig. 1). This is the first report to describe the purification and characterization of the prolidase from the microorganisms including lactic streptococci.

The molecular weight of the enzyme was estimated to be 43,000 by gel filtration. The molecular weight is much smaller than those from pig and bovine intestines, which were $113,000^{10)}$ and $116,000,{ }^{11)}$ respectively. The amino acid composition of the prolidase from Str. cremoris H61 was quite different from that from intestines (Table II). These results suggest that the prolidase from Str. cremoris H61 has different molecular properties from those of intestines. However, the substrate specificity shows the preference of the enzyme for X-Pro type peptides (Table III) as well as those of the enzymes in intestines. These results seem to provide an interesting problem as to why two types of prolidases with different molecular properties exhibit a similar substrate specificity.

The prolidase was completely inhibited by chemical chelators such as EDTA and 1, 10phenanthroline and also by 2-mercaptoethanol (Table V). It is likely that the metal ion locates in the active center of the enzyme. On the other hand, the enzyme from bovine intestine was 
not inhibited by EDTA and markedly inhibited by PCMB. ${ }^{11)}$ The mechanism of catalysis seems to be different from that of the prolidase described here.

The physiological significance of prolidase has been discussed on the enzyme from intestines. Yoshimoto et al. ${ }^{12)}$ reported that the prolidase acted cooperatively with aminopeptidase $\mathbf{M}$ and dipeptidyl aminopeptidase in complete hydrolysis of the peptides in intestine. Therefore, the possibility of contribution of the prolidase described here to the degradation of intracellular protein of Str. cremoris can be considered.

We found that the prolidase reported here hydrolyzed the peptides, derived from $\alpha_{\mathrm{s} 1}$ casein by chymosin, cooperatively with other proteases in Str. cremoris H61 (data not shown). These results suggest that the prolidase contributes to the hydrolysis of X-Pro type dipeptides which might be released by proteinases from milk and lactic streptococci in cheese ripening. Studies on the mechanism of degradation are in progress.

\section{REFERENCES}

1) C. G. Miller, Ann. Rev. Microbiol., 29, 485 (1975).

2) I.-K. Hwang, S. Kaminogawa and K. Yamauchi, Agric. Biol. Chem., 45, 159 (1981).

3) I.-K. Hwang, S. Kaminogawa and K. Yamáuchi, Agric. Biol. Chem., 46, 3049 (1982).

4) M. Bergmann and J. S. Fruton, J. Biol. Chem., 117, 189 (1937).

5) E. Adams and E. L. Smith, J. Biol. Chem., 189, 671 (1952).

6) K. Hui and A. Lajtha, Brain Research, 153, 79 (1978).

7) A. C. Ryden, Acta Chem. Scand., 25, 847 (1971).

8) H. Sjörström, O. Norén and L. Josefsson, Biochim. Biophys. Acta, 327, 475 (1973).

9) H. Sjörström and O. Norén, Biochim. Biophys. Acta, 359, 177 (1974).

10) H. Sjörström and O. Norén, Int. J. Peptide. Prot. Res., 11, 159 (1978).

11) T. Yoshimoto, F. Matsubara, E. Kawano and D. Tsuru, J. Biochem., 94, 1889 (1983).

12) T. Yoshimoto and D. Tsuru, J. Biochem., 94, 619 (1983).

13) A. Yaron and D. Mlyner, Biochem. Biophys. Res. Commun., 32, 658 (1968).

14) A. T. Matheson and B. L. Tattrie, Can. J. Biochem., 42, 95 (1964).

15) O. H. Lowry, N. J. Rosebrough, A. L. Farr and R. J. Randall, J. Biol. Chem., 193, 265 (1951).

16) J. Davis, Ann. N.Y. Acad. Sci., 121, 404 (1964). 